\title{
THE RECONSTRUCTION OF THE NETHERLAND DIKES AFTER THE STORM OF FEBRUARY 1953
}

\author{
J. B. Sohijf
}

Rijkswaterstaat, The Hague, Netherlands

\section{IN TRODUCTION}

The reconstruction of the damage to the dikes by the flood of rebruary 1953 presented an enormous task. From the hydraulic engineer's point of view the most interesting part was the closing of the major or tidal breaches, that is to say, the places where a dike for a certain length was totally destroyed and where, therefor $\theta$, the tides had free entrance to the inundated interior, scouring out deep gullies. This called into action the resouroes of tidal hydraulios, theoretical considerations, and model experiments.

Throughout the region where the gaps occurred, the soil consists of a fairly resistant layer of olay of a few meters thickness at the surface, below which there is a fine sand of a very erodible nature with occasional lenses of clay or peat. Onoe the upper layer of olay has been out through, the breaches as a rule deepen and widen rapidly by scouring of the fine sand. As the broaches beoome wider, the tidal movement in the flooded areas increases. The height of the land in the flooded areas is nearly everywhere below mean sea-level and often at or eren below low water (say $1 \frac{1}{2}$ to $2 \mathrm{~m}$ below mean sea-level). The areas are interseoted by roads, usually somewhat higher than the land, and by ditches and canals. Villages and small towns are mostly situated on somewhat higher ground.

During most of the tidal cyole the land is covered with water and the tide propagates all over the area. Naturally the tidal flow tends to concentrate in the lower sections and in partioular in ditches and canals which happen to have a suitable direotion. These acoordingly are scoured out and in some cases they have beoome power ful tidal oreoks, starting from the breaches and gradually lengthening by regressive erosion. At several of the largest gaps, therefore, $a$ system of radially diverging gullies had developed after some time.

In some of the breaches the upper layer of fairly resistant olay was cut through immediately by the inflowing water, when the dike was breaoked. In many other cases, however, the gap remained relatively shallow at first and it took some time for the orosive aotion of the ourrents to remore the clayey sill. It was espeoially in these cases, as will be readily understood, that speed in undertaking and exeouting the olosing was essential. It was, as a matter of fact, possible in a number of places to prevent the breaohes from beooming really dangerous by a speөdy attaok and improvised mothods. The prinoipal material used in these activities has been the common sandbag. Especially during the first period after the oatastrophe this was an article in great demand. Altogether 15 million sandbags 
THE RECONSTRUCTION OF THE NETHERLAND DIKES AFTER

THE STORM OF FEBRUARY 1953

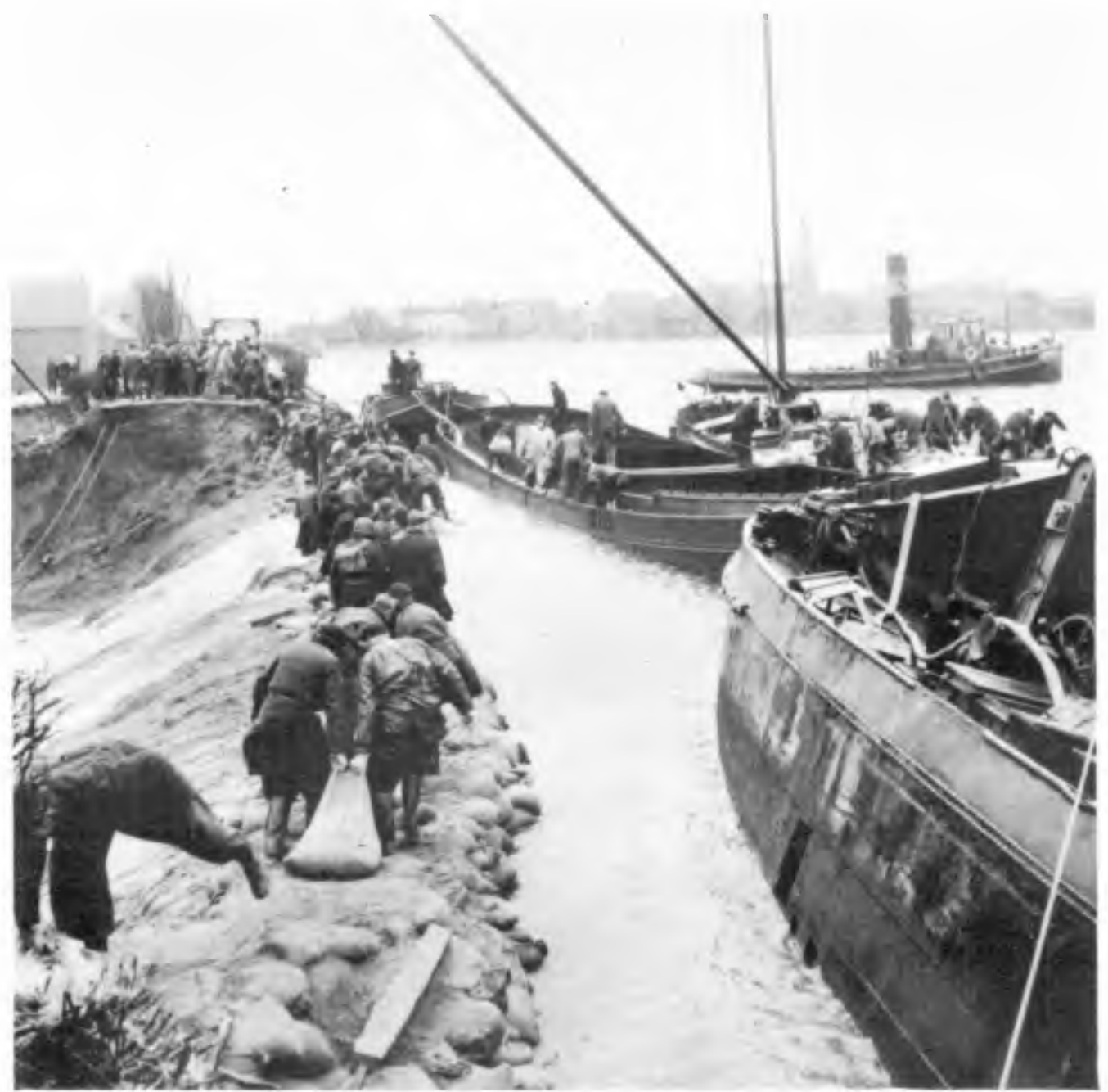

F1g. 1. Plaolng sandbags.

were used. They were transported by land, by water and by air to the danger spots. Not only sandbags were used, but also the stones from the revetment of neighboring dikes, the paving from the streets and many other improvised materials. Fig. 1 serves to give an impression of this activity.

In this way many smaller breaches were - at least provisionally filled before they had a chance of developin into tidal channels. Not in all places, howevor, was this possible; not ovorywere was suffioient labor avallable, or means of transport of material. Some breaches were inacoessible. Moreovor during the first days and oven reeks in sereral regions there was no time for any activity but saving as many lives as possible.

Also, of course, quite a number of breaches were so wide or so deop from the start as to render entirely futile any attempt at closing or even oontrolling them with improvised methods. 


\section{COASTAL ENGINEERING}
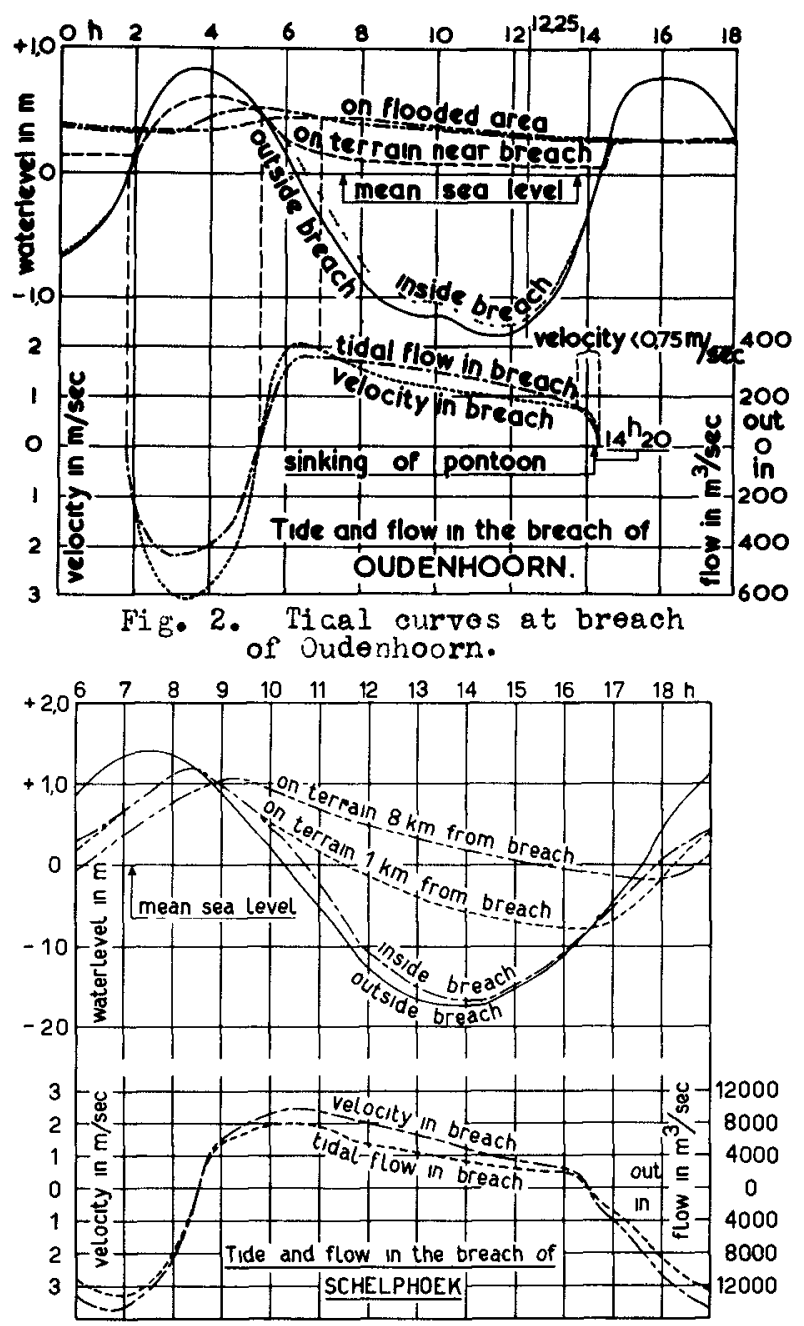

Fig. 3. Tidal curves at breach
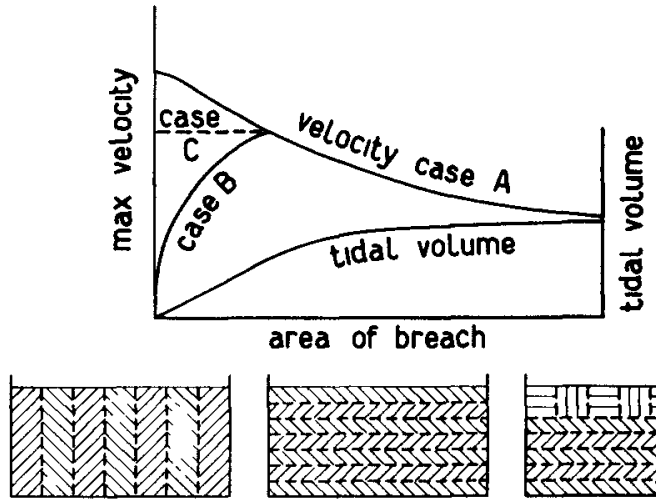

case A
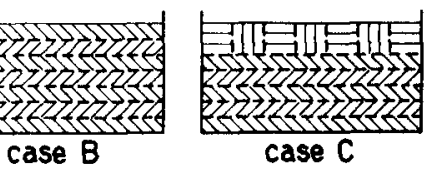

Fig. 4. Tidal volume and flow velooity as function of breach area. 


\section{THE RECONSTRUCTION OF THE NETHERLAND DIKES AFTER}

\section{THE STORM OF FEBRUARY 1953}

After this first stage, say at the end of February, 67 tidal breaches existed, the largest of which was about $400 \mathrm{~m}$ wide, with a maximum depth of about $35 \mathrm{~m}$, givias access to a storare area of $900 \mathrm{sq}$. $\mathrm{km}$, and having a tidal volume varying between 100 and $150 \mathrm{million} \mathrm{m}^{3}$, according to the variations of the tidal amplitude. This, as an illustration, is equal to the volume entering and leaving the mouth of the Rotterdam waterway in every tidal cycle.

\section{TIDAL MOTION}

The first task everywhere was to prevent the breaches from further scouring by protecting the bottom and the sides with fascine matresses and stone, the traditional Dutch practioe, which has been followed for centuries without essential chanjes. At the same time an extensive reconnaissance by sounding, ourrent measuring and ooservation of the tides in the flooded areas was carried out. By means of model experiments and ticlal oalculations these data (subject to continual and sometimes even fairly rapid changes) were correlated in order to obtain a comprehensive picture of the hydrographio and hydraulic situation, which could be used as a base for planning the strategy and tactios of the closing operations. This planning should be understood to be rather like the planning of a chess player who has to be ready to revise his strategy and tactics according to the mores of his opponent, and not the drawing up of a definite plan to be followed in detail to the very end.

In this stage it may be useful to make a few remarks of a general nature on the procedure of closing off a tidal storage area. Given a gap of a certain cross-seotional area feeding a certain area of storage lying at a certain level with regard to the mean water level outside, with a oertain amplitude of the tide and a certain value of the resistance in the breach, in the gullies and on the terrain, a definite picture oan be made of the tidal movement in the storage area and the associated flood and ebb flow through the gap. Figs. 2 and 3 show this condition for two of the breaches. If the gap is gradually narrowed the amplitude of the tides on the terrain will diminish and also the total flow will diminish, but the flow velocity in the gap will increase. This is presented for a hypothetioal case in Fig. 4 (case.A. When the gap is nearly olosed, the rise and fall inside will be practically nil, but the velocity in the gap will be at its maximum. Given sufficient data at the start, it is possible to predict by calculation or model experinent to a sufficient degree of acouracy the trend of the changes and the values to be expected in every stage of the olosing. For the sake of simplicity oertain complioating faotors are left out of oonsideration for the moment, such as the fluotuation of spring and neap tides, abnormal high tides by wind aotion and the opportunity that presents itself in some cases of eliminating a part of the storage area. These factors will find their place later, when a few cases are discussed.

\section{GENERAL PROCEDURE OF CLOSING}

With the tidal ranges enoountered in the Southwestern estuaries of the Netherlands $(3$ to $5 \mathrm{~m}$ ) it is found that the flow velootties at the end will be too high for any of the available materials (sand, clay) exoept heary stones. A dam of stones, however, besides being expensive, takes a long time to build, especially as the slack water periods at the transition 
betweon flood and $\theta b b$ flow, and vice versa, become progressively short. Moreover, the continuous transport of large quantities of stone presents difficulties. It should be remembered that stone has to be imported from other countries (Belgium or Germany) and that also much stone is neoded for ballasting the brush-wood mattresses.

In most cases, therefore, another method has been followed. This consists in narrowing the gap to a oertain width, wide enough for the velocities to remain below a critical value. This value is not a constant, but depends on the local conditions, the nature of the soil, etc. In general It should not be over 3 to $3.5 \mathrm{~m} / \mathrm{seo}$, at an average tide. The gap thus left is then closed in a single operation. In this way the last stage of the olosing, the stage in which the flow velocities grow to dangerous values, is, as it were, out off. Our ancestors have followed a similar method. They used a ship for the final operation. This has also been done now in some cases, but mostly use is made of concrete pontoons.

There was one case, however, in which this pontoon method oould not solve the problem. This was the largest breach of all. Her $\theta$, in order to keop the flow velooities below the oritical value, a final gap of something like $3000 \mathrm{~m}^{2}$ would have had to be closed in one operation. This would have meant the use of, for instance, a pontoon $2.00 \mathrm{~m}$ long reaching to $15 \mathrm{~m}$ below mean sea lovel, which was out of the question.

Here it was necossary to follow a different method, a method which would avoid increasing the flow velocities to excessive values. This oan be done if the gap is narrowed by building up uniformly from the bottom. In this case, when the crest reaches a oortain level a state of maximum overflow prevails. Then the downstream water level has no influence on the velocity of the flow any more, and further restriotion of the gap does not lead to higher velocities (Fig. 4, cases $B$ and $C$ ).

The crux of this mothod is to have sufficient width so that the velocity at the stage where the maximum overflow occurs is below or equal to the oritical velocity which can be accopted under the prevailing conditions. The need for the instantaneous closin $b_{b}$ of the remaining gap is thus eliminated. This might be termed the high crest olosing mothod. A sufficient width for this purpose is usually not to be found in the breach itself. Moreover, the actual breach is as a rule not suitable for building up a dem with a fairly high crest, among other reasons, because of its great initial depth. Whon applying this mothod of closing, one is therefore led to leave the breach alone and to construot a new embankment some distance inland, enciroling the breach and theroby sacrificing temporarily a certain area of land. The base of this embankment is then on the level of the terrain, so that a crest of sufficient height for insurin maximum overflow is more easily obtained. As will be shown later, in the case of Schelphoek, our largest breach, a retreat of about $1 \mathrm{~km}$ was made and an embankment of $4 \mathrm{~km}$ longth was construoted instead of directly closing the $600 \mathrm{~m}$ wide gap. It will also be shown that as the situation developed, it was not a high orest closing procodure in the full sense, as had originally been planned, 


\section{THE RECONSTRUCTION OF THE NETHERLAND DIKES AFTER}

\section{THE STORM OF FEBRUARY 1953}

but a case of the chess player on the other side of the board obstructing the well thought-out moves.

After this disoussion on general procedure, three breaches have beon selected for a more detailed treatment, first one of the smaller ones that could be finished relatively early, the largest one, and the one that unexpectedly got out of control and consequently was the last gap of all to be olosed.

\section{THE BREACH OF OUDENHOORN}

A week after the gale, the breach of Oudenhoorn had a width of about $70 \mathrm{~m}$ and a depth of $5 \frac{7}{2} \mathrm{~m}$ below mean sea level (FYg. 5). At that depth a layer of fairly resistant olay was enoountered which for the time being prevented further orosion. At first the area flooded by this breaoh was $37 \mathrm{sq}$. $\mathrm{km}$, but by repairing some inland embankments it. was soon possible to reduoe the area to $26 \mathrm{sq}$. $\mathrm{km}$. The terrain was on the average situated slightly above mean sea-level. The tidal volume was about 10 million $\mathrm{m}^{3}$, which caused maximum volooitios in the gap of about $3 \mathrm{~m} / \mathrm{seo}$. Fig. 2 shows a fow typioal tidel curves and the velocity curve in the gap. These ourves represent a neap tide. At spring tide the tidal differences and the velooities are higher.

For closing the breach two concrete ships were at hand, which had boen used as floating tanks. They had a longth of $25 \mathrm{~m}$ each and by oombining the two by means of steel girders and sheets, a unit could be obtained of $51 \mathrm{~m}$ length, $5.8 \mathrm{~m}$ in width and $5.6 \mathrm{~m}$ in height. At both onds a stool scaffolding was oreoted supporting steol shoot piles which could be dropped by remoring a ratchet. This construotion was ohristened, "guillotine".

In the time needed to lash together the two hulls and to equip this unit with the guillotine and other neoessities, the bottom of the gap was raised by brush mattersses and stone to $4.4 \mathrm{~m}$ below mean sealevel. The top of the pontoon $(5.6 \mathrm{~m} \mathrm{high})$ therefore reached to $1.2 \mathrm{~m}$ above mean sea-level; that is, the top was slightly above mean high water. The ends of the dike at both sides of the gap were more or less trimmed by stone.

The olosing operation had to be oarried out at slack tide, either at high water or at low water (Fig. 2). For two reasons the low slack tide, that is, at the ond of the obb flow was indicated. In the first place, the period of moderate volooities during which the unit has to be maneuvered into position and sunk was somewhat longer. In fact, for about fifteen minutes the flow was below $3 / 4 \mathrm{~m} / \mathrm{sec}$. In the seoond plaoe, less time would be noeded for sinking, because of the lower initial level. As the draft of the pontoon was $2.2 \mathrm{~m}$ and the expected level at the slack time would be about mean sea-level, the pontoon had to sink over $4.4-2.2$ or $2.2 \mathrm{~m}$. For sinking the pontoon, the sides of the hulls were pieroed and the holes were closed by means of flaps which could be opened by removing a ratohet.

Evorything was ready for the olosing operation on February 28. 


\section{COASTAL ENGINEERING}

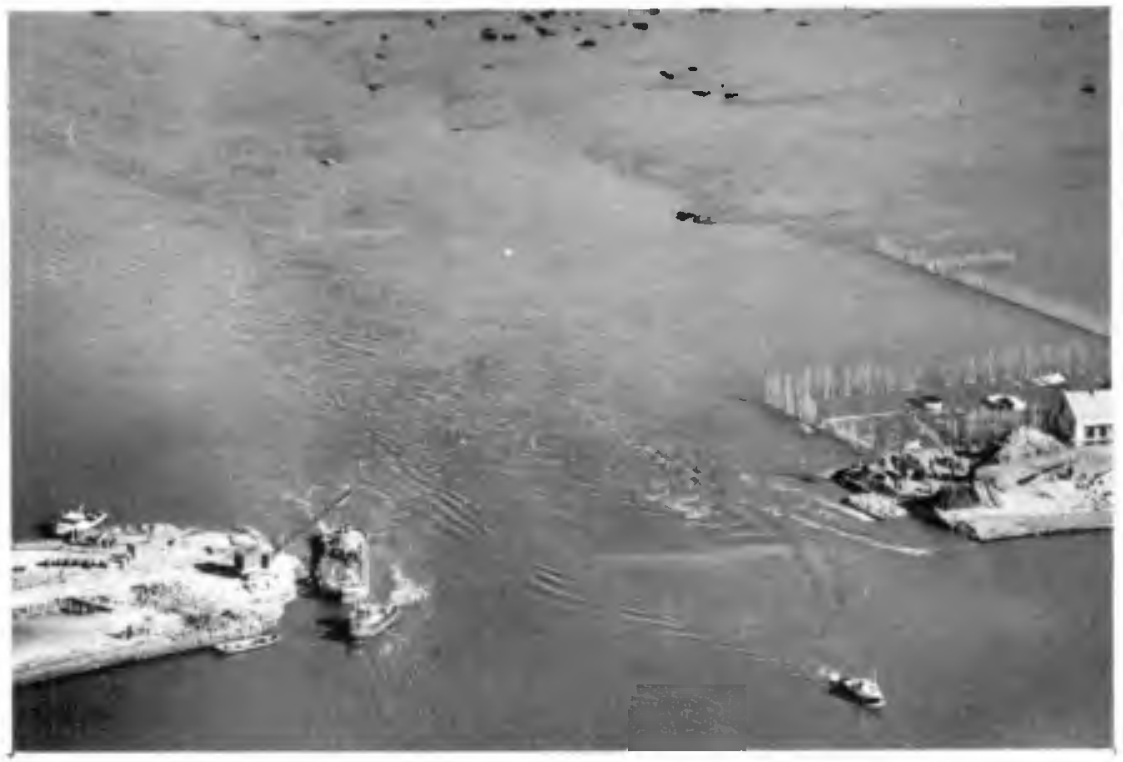

Fig. 5. Breach at Oudenhoorn.

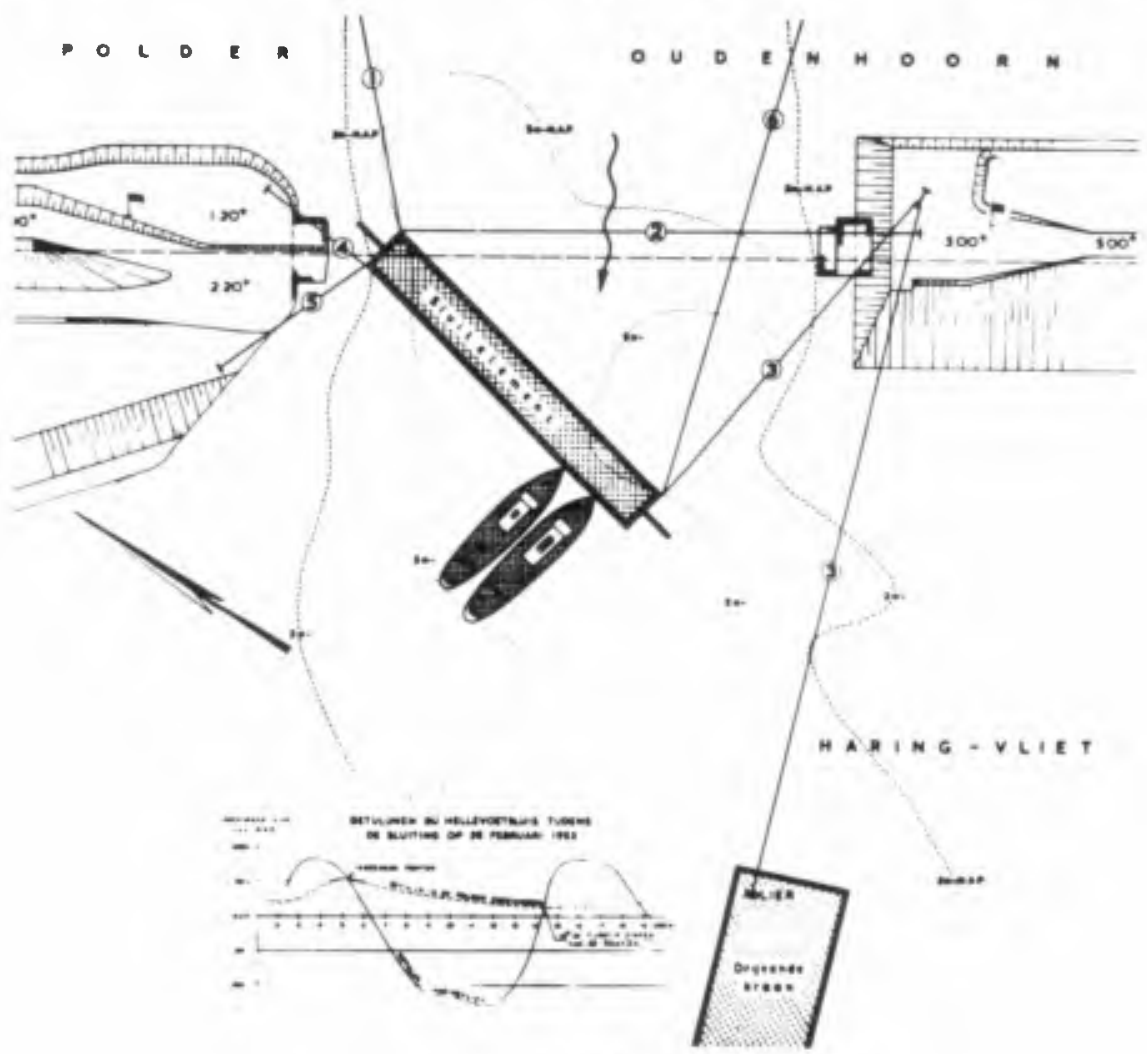

FIg. 6. Closing scheme Oudenhoorn. 


\section{THE RECONSTRUCTION OF THE NETHERLAND DIKES AFTER}

\section{THE STORM OF FEBRUARY 1953}

Experiments had been carried out in the hydraulic laboratory from which the method shown in Fig. 6 was chosen. The pontoon was moored beforehand at one ond by means of oables 1,4 , and 5. The actual maneuvering into position was effected mainly by cable 3, controlled by a winch of a floating orane at anchor. Cables 2 and 6, as well as 1 , served only for emergenoy purposes.

As soon as the ebb flow had slackened sufficiently, the operation was started. There was a slight delay bocause the pontoon touched bottom on a protruding edge of a fascine mattress whioh had not sunk properly. As the tide was rising during the operation, the pontoon floated freo just in time. It was maneuvered exactly into position and sunk within fow minutes (Fig. 7).

This however was by no means the end of the operation. The pontoon with its equipment had a weight of about 700 tons. As can be seen from the tidal curve, the water was rising rather rapidly at the moment of closing and very soon at high water the pontoon would have to withstand a head of say $3 / 4 \mathrm{~m}$, that is to say a horizontal pressure of some 200 tons. Moreover the outward pressure at low water would be nearly twice as much. As from previous experience and from special experiments it was established that the friction coeffioient of a oonorete pontoon on a bed of dumped stone is about 1,3 , the total weight had to be brought within a few hours to at least 1200 tons. This was done by pumping sand onto the hulls, for which purpose a pipeline was laid on the pontoon, ready to be connected to a pipeline along the dike immediately after sinking. At the same time stones were dumped between the onds of the pontoon and the dike ends, and both in front of and behind the pontoon, to be followed later by clay in order to seal off the loaks left by the imperfeot fitting of the concrete pontoon on the rough bed.

Upon completion of the above operation,a full dike of sand covered by olay and stone revetment was built around and on top of the pontoon and this breach was completely closed.

\section{THE EREACH OF SCHELPHOER}

The largest and most difficult breach was that of Soholphoek on the island of Schouwen (Fig. 9). At the time of the first survey it was $300 \mathrm{~m}$ wide and the greatest depth was $30 \mathrm{~m}$ (Fig. 8). Later it gew to a width of more than $500 \mathrm{~m}$ with a maximum depth of $35 \mathrm{~m}$. Gullies, devoloping into largo tidal oreoks, were eating their way inland at a rate of 300 to $400 \mathrm{~m}$ per week (compare Figs.10 and 11). The tidal volume was, aftor some time, between 120 and 150 million cubio meters, with a maximum flow of some 14,000 oubio meters per sec, whioh is more than the maximum discharge of the Rhine. A pioture of the tidal motion is shown in Fig. 3 .

It was quite out of the question to deal with this grandfather of all breaches in the samo way as at Oudenhoorn. Therefore, it was decided 
COASTAL ENGINEERING

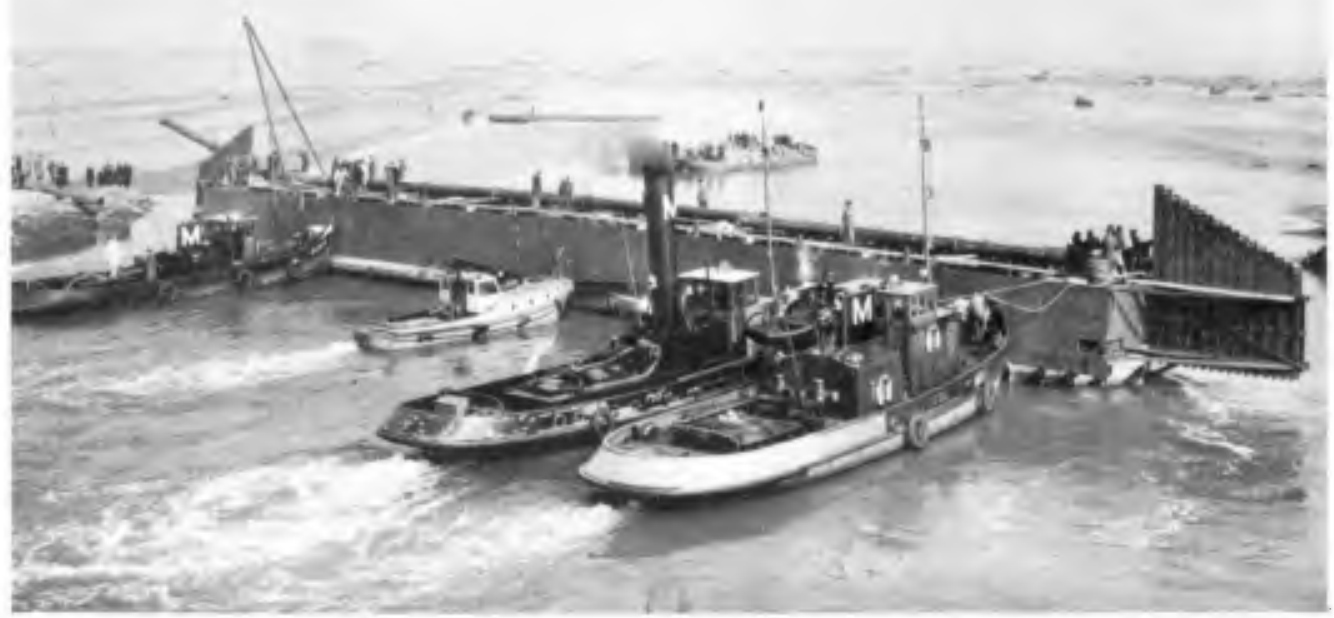

Flg. 7. Pontoon under way.

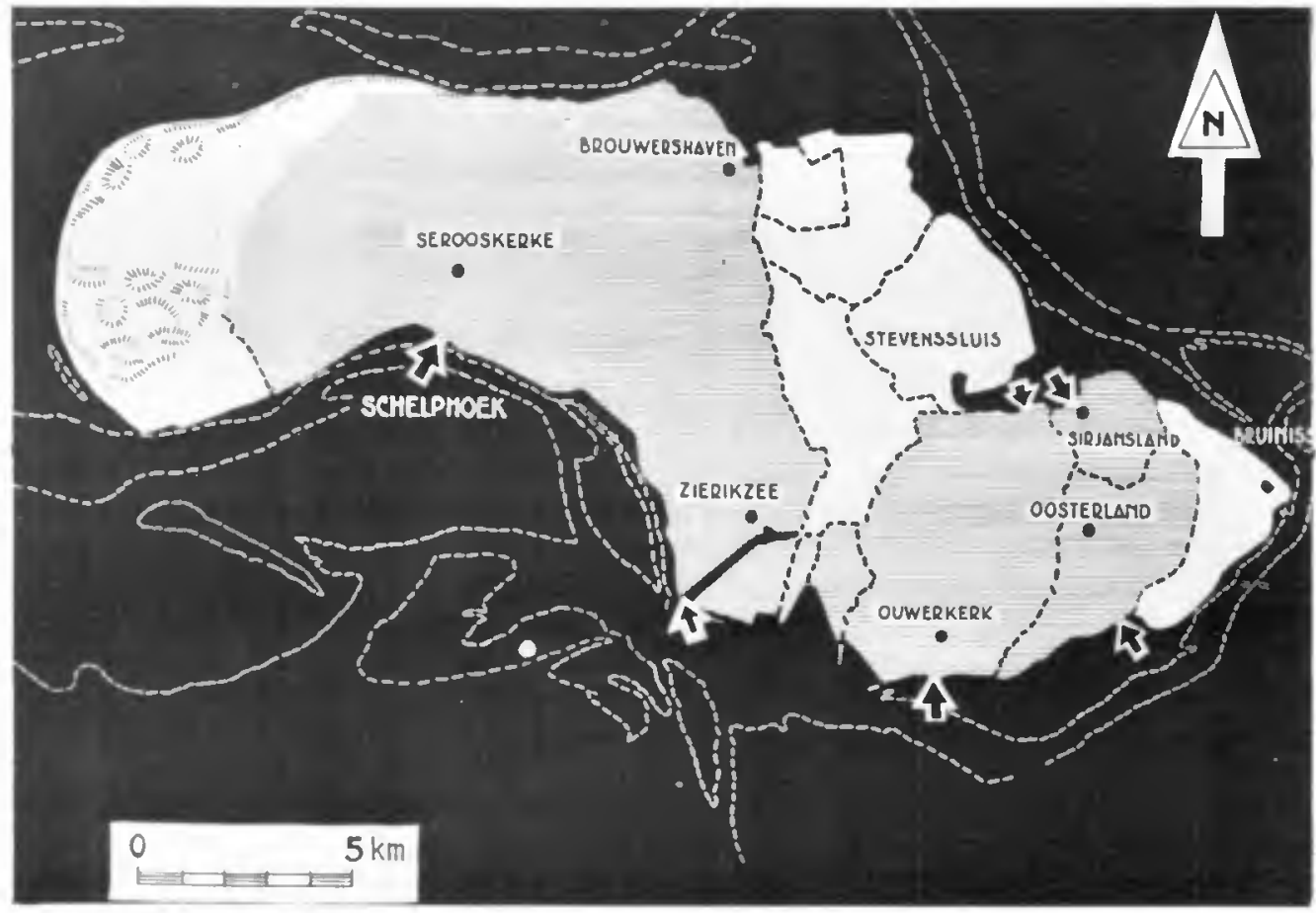

Fig. 8. Is land Sohouwen-Duivoland. 
THE RECONSTRUCTION OF THE NETHERLAND DIKES AFTER

THE STORM OF FEBRUARY 1953

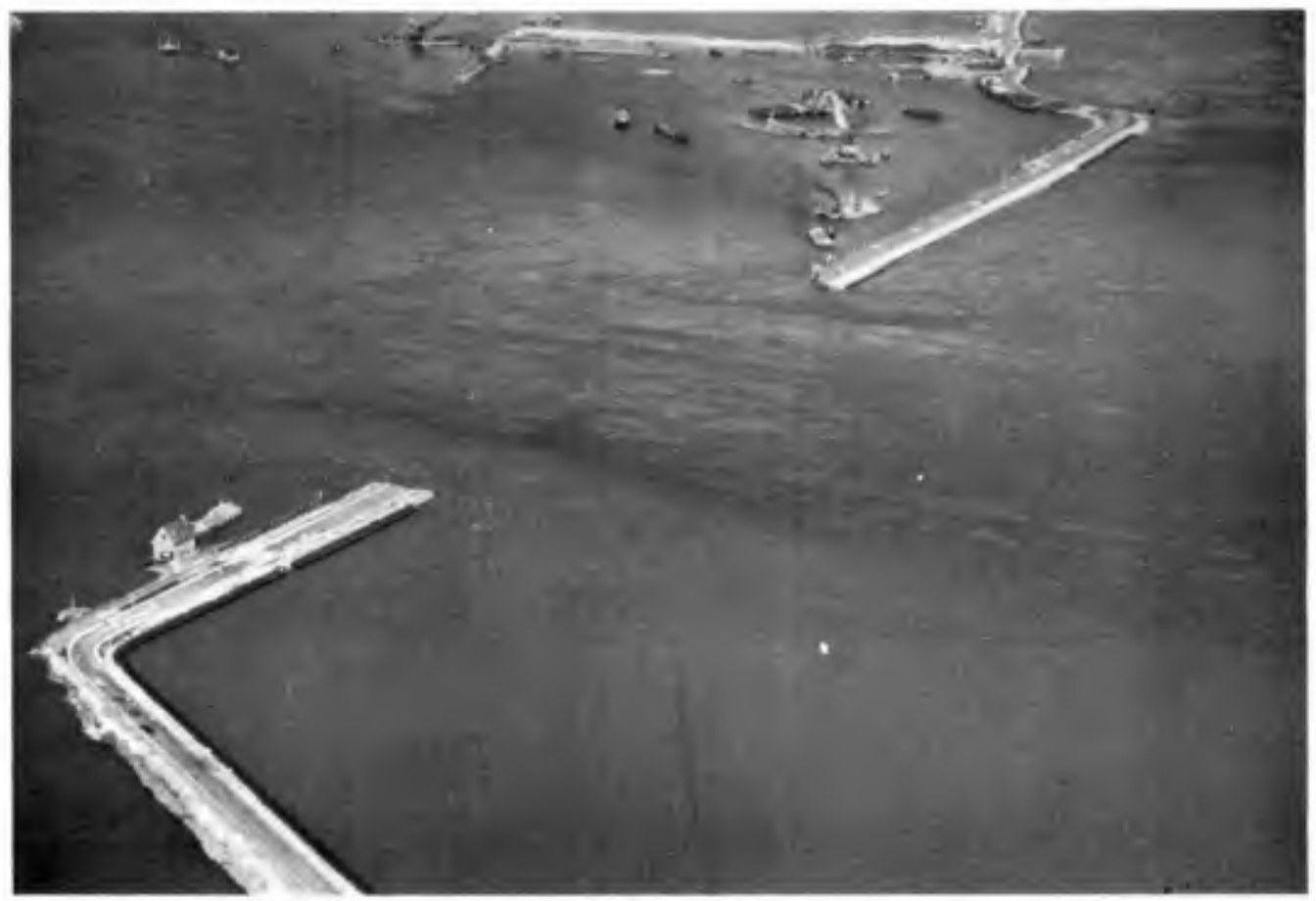

Fig. 9. Breach Sohelphoek at high water.

to encircle the breach by a high crest overflow dam. Calculation showed that its length should have to be about $3 \mathrm{~km}$. In the center, just opposite the breach, was the village of Serooskerke, at a distance of nearly

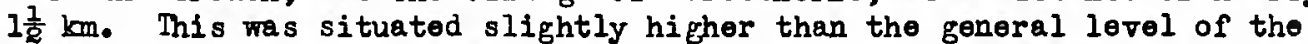
terrain, whioh varied between 1 and $l \frac{1}{2} \mathrm{~m}$ below mean sea level. As the higher ground around the village did not contribute materially to the flow to and from the breach,and in order to keep the village inland of the embankment, this was fixed at a short distanoe in front of the village at about $1 \mathrm{~km}$ from the gap. From there an alignment was projected, ourving gradually to the dike at both sides of the breach (Fig. 12). The embankinent was to join the dikes at looations which for practical reasons offered suitable positions for floating pumping stations dolivering sand for the embankment by means of pipelines. On the higher ground in front of Serooskerke the embankment was built immediately to above the high-tide level by hydraulio fill, using a suotion dredger with floating pipeline, pumping sand between clay mounds built with olay from the site by clam shell dredges. The same was done for a short distanoe from the dikes at both sides of the breach in order to oreate starting 
COASTAL ENGINEERING

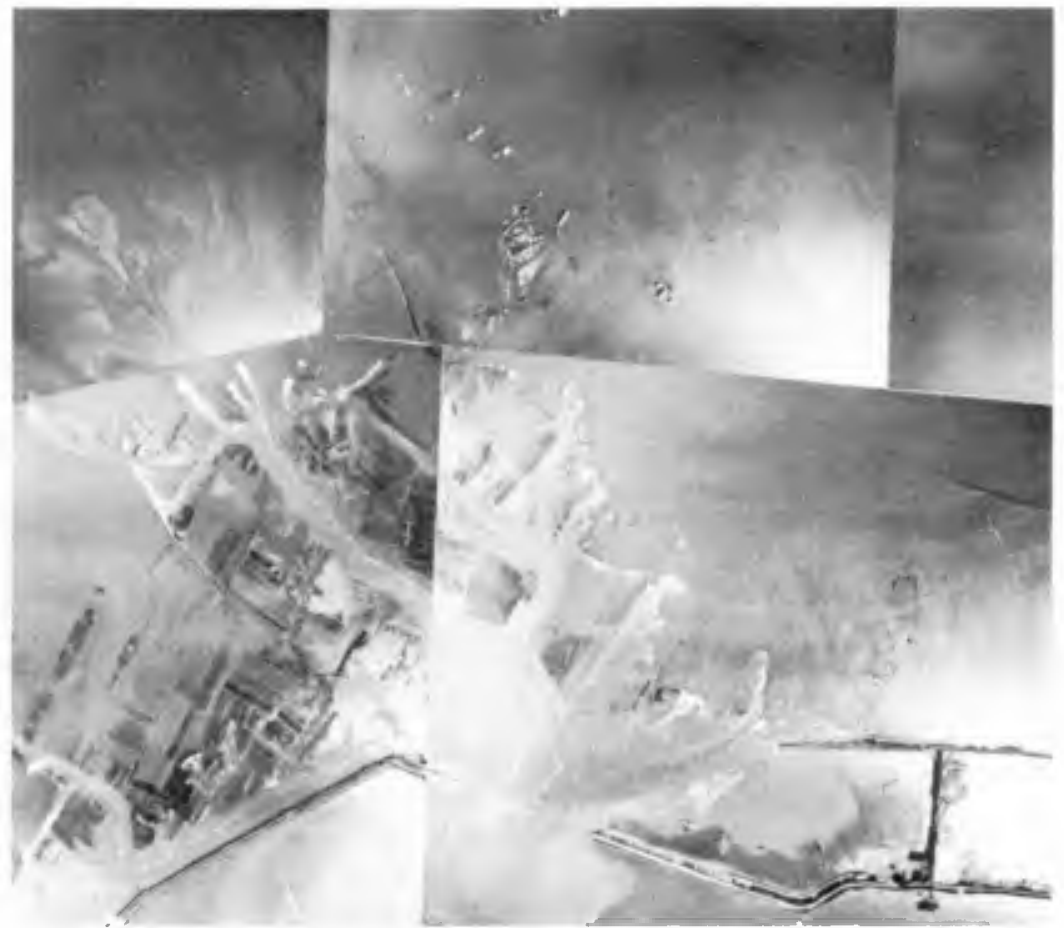

Fig. 10. Aerial viow May 1, 1953.

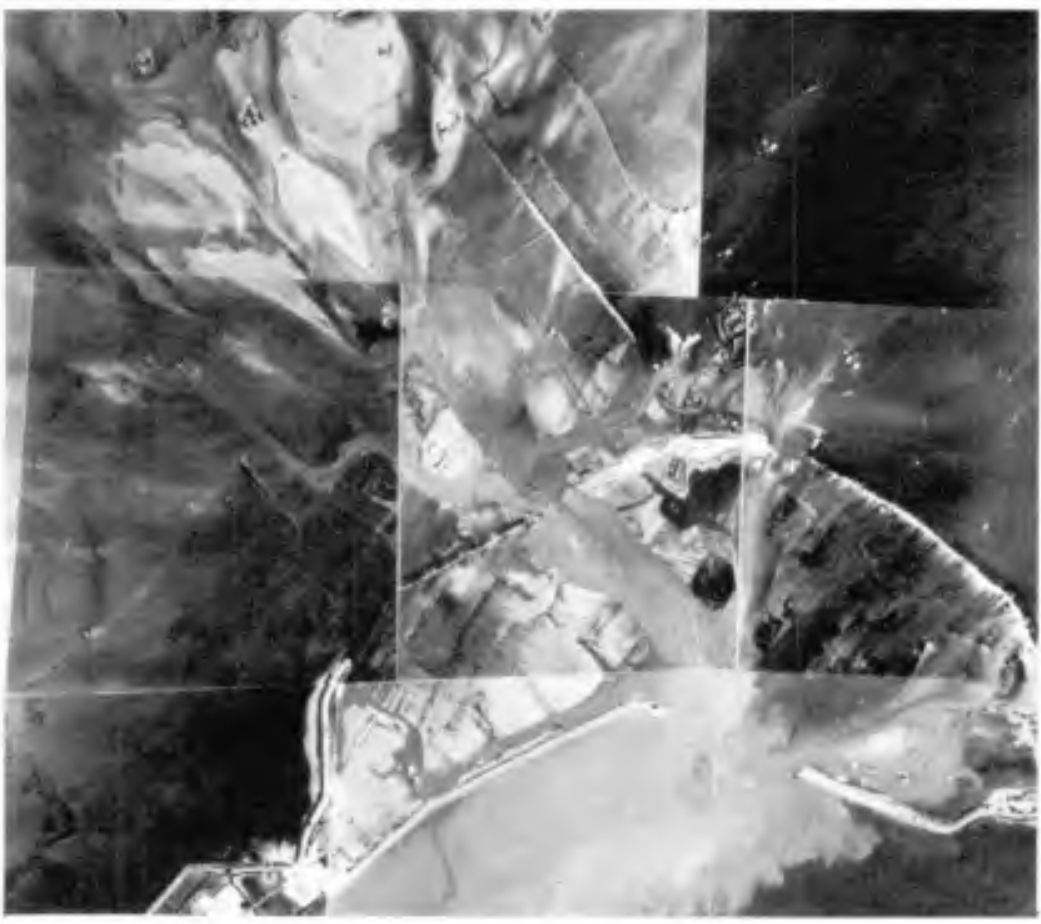

Fig. 11. Aerial view August 1, 1953. 


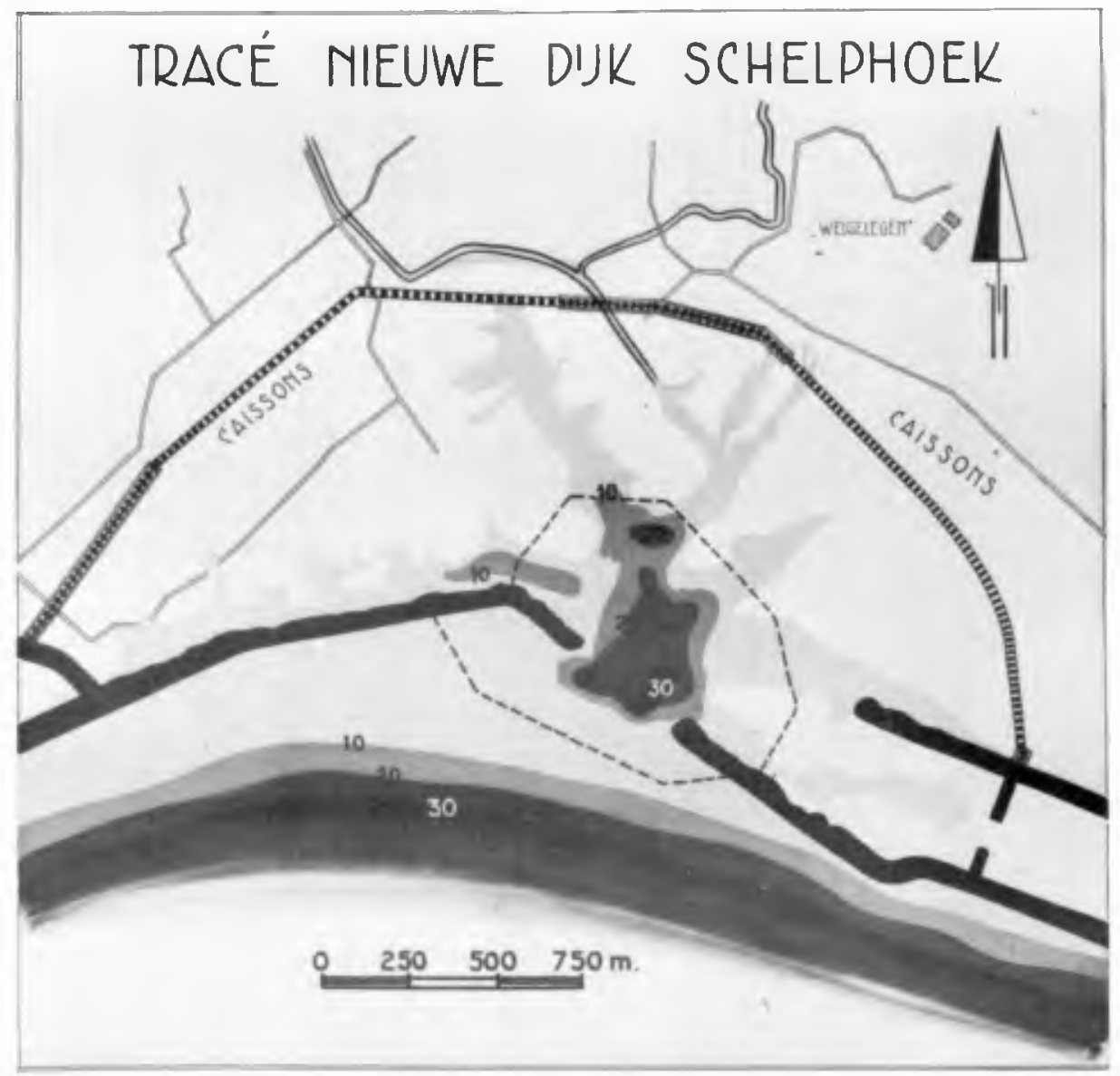

Fig. 12. Alignment of embankment at Sohelphoek.

points for the oonstruction of the final embankment. Both east and west of the village in this way there remained some $1500 \mathrm{~m}$, making $3000 \mathrm{~m}$ altogether for the overflow crest, and the total length of the embankment was to be $4 \mathrm{~km}$.

According to the plans a $40 \mathrm{~m}$ wide strip of brushwood mattress had to be laid and loaded with stone over the entire length of $3 \mathrm{~km}$. This would form a crest, varying in level from mean sea level to $1 / 2 \mathrm{~m}$ below it, suffioient to create maximum overflow conditions everywhere (Fig. 13). On this foundation conorete pontoons $11 \mathrm{~m}$ long, $7.5 \mathrm{~m}$ wide and 2 to $3 \mathrm{~m}$ high were finally placed so as to reach everywhere to at least 2 m above mean sea level (slightly above spring high water). When sunk and filled with water, these pontoons were caloulated to be able to wistand the pressure of the tidal differences. They were to form the nucleus of the final embankment.

The project however oould not be oarried out unchanged. While the construction of the embankment at the center and at the flanks, and at the same time the sinking and loading of the brushwood strip was 


\section{COASTAL ENGINEERING}

progressing, two of the gullies eroded their way inland beyond the projected alignment of the dam. One of them eroded at such a rate in the northwesterly direction that a shifting of the alignment of the dam in order to keep ahead of it was out of the question. "herefore, the project had to Le revised in the followng way. The embankment was to cross the gullies in a suitaple place. The bottom and sides of the gullies were to be covered by fasoine mattresses in order to prevent further deepening and widening at the sites of the crossinss. Before starting to place pontoons on the brushwood strip the gullies were to be closed by means of concrete pontoons.

As this revision of the project entailed an increase in the amount of fascine work and therefore prolonged the time needed for this part of the projeot, it was decided meanwhile to extend the embankment at full height at the two extreme ends of the alignment. This was made posible from a hydraulio point of view because the oross-seotions of the gullies were added to the total cross-section area available for the flow. Accordingly the length of the high crest dam could be safely diminished to $900 \mathrm{~m}$ at the west side and $1100 \mathrm{~m}$ at the east side of Serooskerke.

It took some time to get the work under way. There was no harbor or shelter within easy distance to serve as a base and as a refuge in case of bad weather for the fleet of dredges, cranes, barges, tugs, surveyressels and other floating oquipment needed for a job of this scale. There was no accomodation for the laborers, no suitable site for workshops, office huts, no so called "zate" for construoting the brushwood mattresses. A "zate" is a beach or other fairly even surface, dry at low water and just submerged at high water to allow for floating the finished mattresses. All this had to be created first. Two harbors, one to the west and one to the east of the breaoh, were dredged out in bights shelterod by protecting ends of abandoned dikes from flood disasters in the past (in this region history records repeated retreats from the assaults of the sea). The spoils from the dredging were used for raising areas for huts, workshops, etc. Because of these necessary preparations it was near the end of May when the activities were in full swing. by that time there were in action around the island of Schouwen-Duiveland alone, 5 bucket-dredges,. 33 suction dredges, 126 tugs, 266 barges of different description, 17 floating cranes, 105 draglines and numerous smaller units. The greater part of this equipment was employed at the Schelphoek breach.

In the operation 15,000 tons of stone, $30,000 \mathrm{~m}^{3}$ of clay and $300,000 \mathrm{~m}^{2}$ of sand were delivered and used per week. Also 15 to $20,000 \mathrm{~m}^{2}$ of brushwood mattresses were oonstructed weekly, sunk and loaddd with stone. Near nid-August the $2 \mathrm{kn}$ brushwood sill was put in place, the two gullies were provided with a protection against further erosion of the bottom and the sides, and the embankments in the center of the two ends of the alignment were in suitable condition. The velocities in the gullies had inoreased by then to $3 \frac{1}{2}$ to $4 \mathrm{~m}$ per of the gullies.

The biggest type of concrete pontoon available was the Phoenix Ax from Mulberry Equipment, a small number of which had been left in England from the war. They were $62 \mathrm{~m}$ long, $18 \mathrm{~m}$ broad and $18 \mathrm{~m}$ high, when floating they had a displacement of 7000 metric tons. They were brought over from England for use in closing the largest breaches. 
THE RECONSTRUCTION OF THE NETHERLAND DIKES AFTER THE STORM OF FEBRUARY 1953

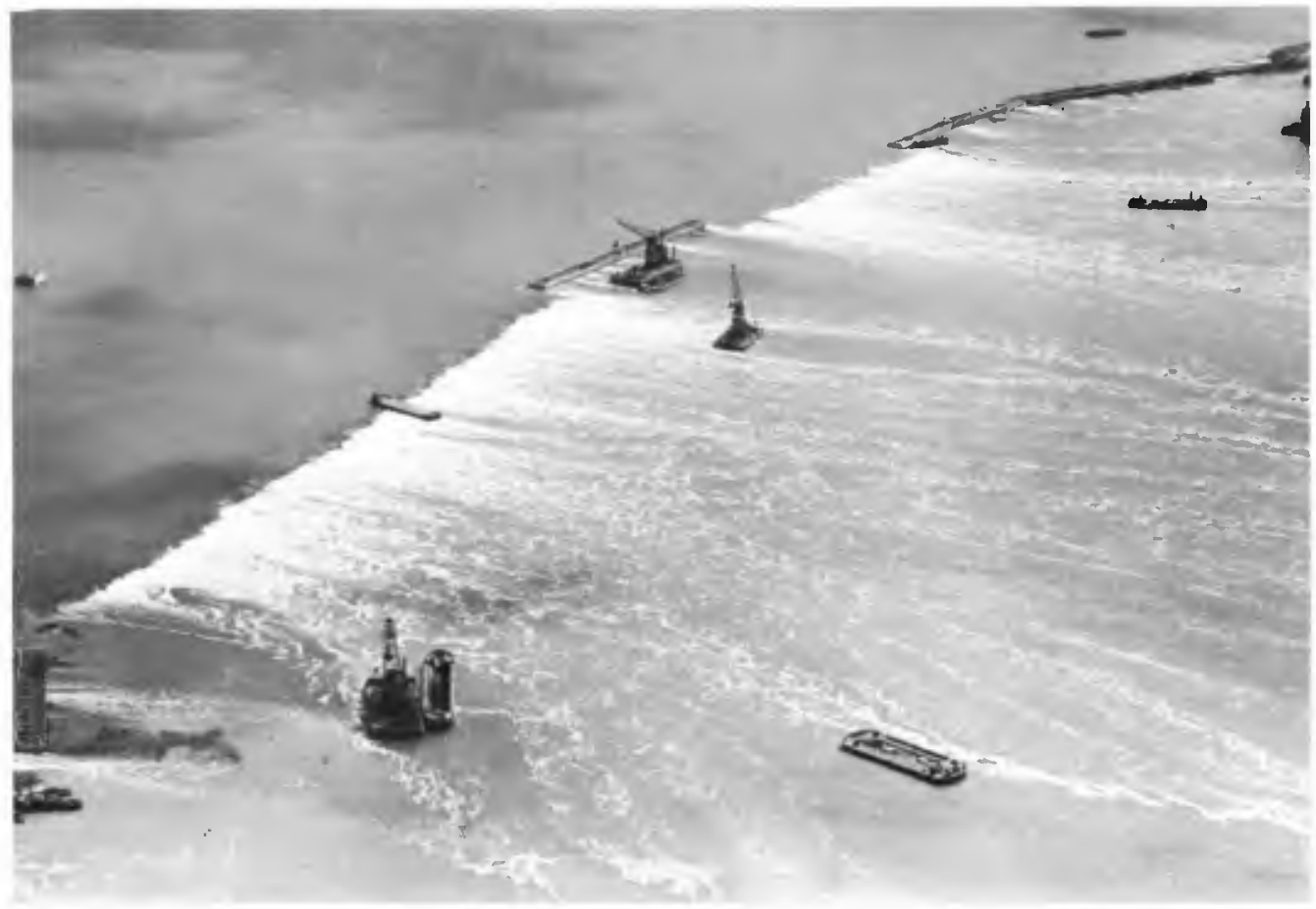

Fig. 13. Overflow crest.

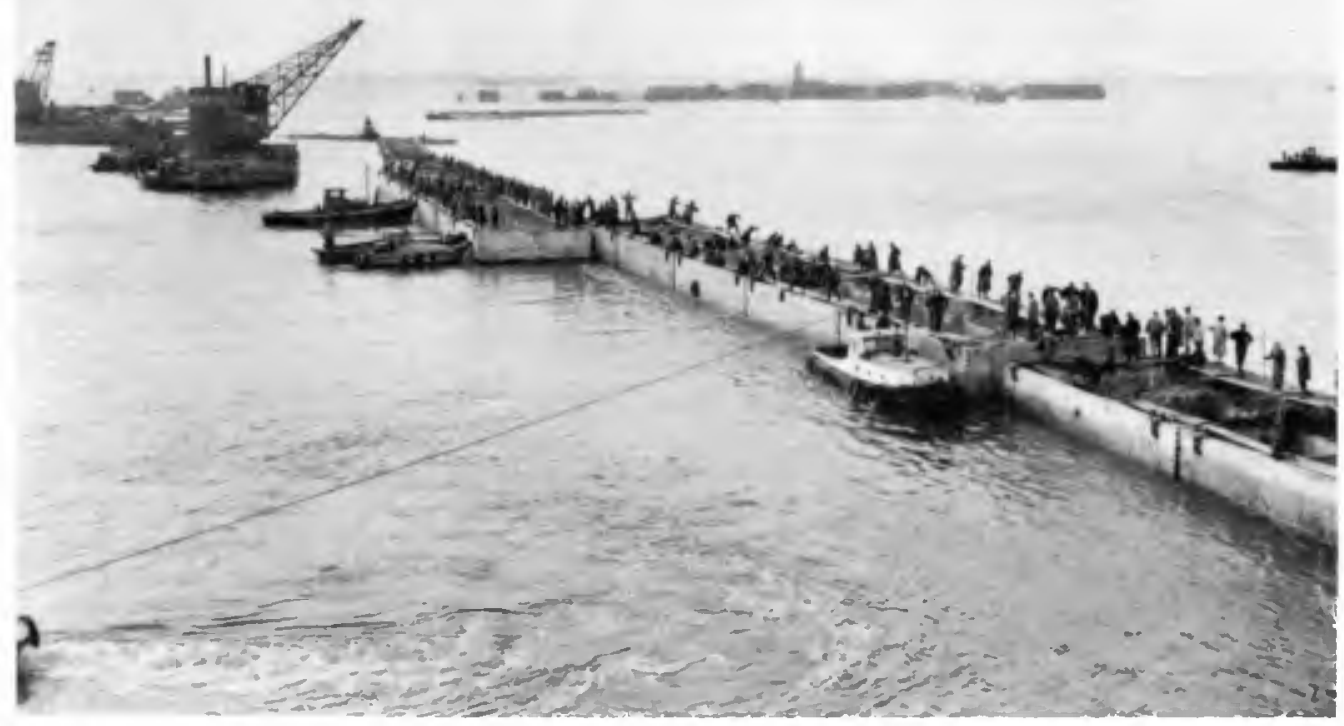

Fig. 14. Closing oast gap. 


\section{COASTAL ENGINEERING}

The gully west of Serooskerke was $100 \mathrm{~m}$ wide, and the base of dumped stone on the brushwood mattresses which was to reoeive the pontoon was at $10 \mathrm{~m}$ bolow mean sea level. Before placing the pontoons, the gap had to be trimmed to the length of the pontoon. This was done by placing smaller pontoons which had been construoted sinoe February. It was realized immediately after the flood that oonorete pontoons in great quantities would be needed for the olosing of the numerous breaches and accordingly orders were placed with a group of several large contracting companies for the construction of standardized units which could be cambined into pontoons of different sizes, acoording to the needs. The dimensions chosen for the units were $11 \mathrm{~m}$ long and $7.5 \mathrm{~m}$ wide. The assembled pontoons accordingly could have lengths of either $\mathrm{n} \times 7.5$ or $\mathrm{n} \times 11 \mathrm{~m}$ and heights of $2,4,6$ otc. up to $14 \mathrm{~m}$. It was also possible by slight modifications to have intermediate heights.

By means of combining suitably chosen pontoons from this stock and dumped stone, the width of the west gully was restricted to $60 \mathrm{~m}$. This immediately resulted in a local inorease of the flow velooitios and in increased erosion along the edges of the protective layer of the brushwood mattresses. The most dangerous factors were the vortex trails starting from the edges of the outer pontoons. The proteotion, originally practioally flush with the bed of the gully, formed a sill with undesirably steop slopes. In the extremely fine sand slides bogan to oocur, which resulted in subsidence of some of the oonorete pontoons restricting the width. At that mornent an important decision had to be made. Either the big pontoon for closing of $f$ the gully would have to be put into plaoe immediately or this would have to be delayed until the solidity of the base layer could be improved by extending and reinforoing the proteotive layer and dumping more stone.

If the first course was to be followed, further erosion oould be stopped but the danger of the entire construotion sliding down into one of the deop excarations of $30 \mathrm{~m}$ at both sides of the sill was a possibility. Moreover, the closing of the west gully would have to be followed with a minimum of delay by the olosing of the east gully, because the inoreased flow would increase erosion in that place.

On the other hand, it was by no means certain that it would be possible by continued sinking of mattresses and dumping stones to gain the upper hand of the rapidly progressing erosion. Moreover, the ond of August was nearing, which would bring high spring tides and the possibility of an early autumn gale - they have been known to oocur in the first days of September

It was a matter of weighing chances, none of which oould be assessed quantitatively. Yet it was felt by ereryone concerned that the bold course had to be taken; aooordingly, on the 18th of August the big pontoon was maneuvered into place and sunk, as usual at the end of the ebb tide. Again the maneuver had been carefully rehearsed in the hydraulio laboratory and the operation went exactly acoording to schedule. 


\section{THE STORM OF FEBRUARY 1953}

Two days later a pontoon was placed in the east gully. Although this was a smaller pontoon, the operation was difficult because it had to be carried out at the slack tide near high water as the depth at low water was insufficient. The time available was very short, and on this oocasion the pontoon had to be held by cobles and eased-off wi th the decreasing flood ourrent instead of pulled against the last ebb flow. Howerer, once again all went well and the most dangerous part of the closing of the Schelphook breach past.

Then followed a time of feverish activity in consolidating the position of the two pontoons and sealing the gaps, left below and at the sides, with stone, olay and ultimately sand. At the same time the two stretches of the alignmant on the terrain were closed by means of a large number of smaller pontoons ( 2 to $3 \mathrm{~m} \mathrm{high}$ ) mostly operated in strings of 4 to 6 (Fig. 14). By the end of September the entire ring was closed, although it still took much labor and care to seal all leaks and to convert the slender line of rather flimsy conarete boxes into an embankment capable of withstanding the winter gales. By that time the hope of also closing the breach itself before winter had been given up. It had been planned to use for that purpose 4 or 5 of the big Phoenix pontoons, but as it turned out they were neoded at another place. This was the breach at ouwerkerk, the last one to be olosed and the last one we will discuss.

\section{THE BREACHES AT OUWERKERK}

Ouwerkerk is a small village in the eastern half of the twin island Schouwen-Duiveland (Fig. 8). This half is dividod by two inland embankments into three polders, all of which wore flooded. The sea entered through five tidal breaches, two of which were situated near to each other just south of Ouwerkerk. The three other breaches all could be olosed wi thout too great difficulties. Also the two embankments separating the polders had been repaired by the boginning of August. This had been a muoh more troublesome affair because of the diffioult transport and the impossibility of putting big equipment to work.

In front of the dike at Ouwerkerk there was a shallow shelf or foreland several hundred meters wide. As the dike between and adjoining the gaps was badly damaged also, it was deolded to construct a new dike in front of the old one over a length of $2.2 \mathrm{~km}$ (Fig. 15). Starting from the breaches in the dike, gullies had been sooured out both in the polder and through the foreland. It was deolded to build the parts of the dike on the higher stretohes of the foreland first and to leave the gullies for the final closing. Of course the bottom and sides of the gullies were protected first with brushwood mattresses.

The area served by the two gaps was $27 \mathrm{~m}^{2}$ with a tidal volume of about $40 \mathrm{milli}$ o $\mathrm{m}^{3}$. It was caloulated that a total area of the two final gaps of $1200 \mathrm{~m}^{2}, 800 \mathrm{~m}^{2}$ oast and $400 \mathrm{~m}^{2}$ west, would bo suffiolent to keop the maximum velooities below the limit of $3 \frac{t}{2} \mathrm{~m} / \mathrm{sec}$. Both gaps were to be olosed by means of concrete pontoons assembled from standard units on two successive days in a woek of noap tides. 
COASTAL ENGINEERING

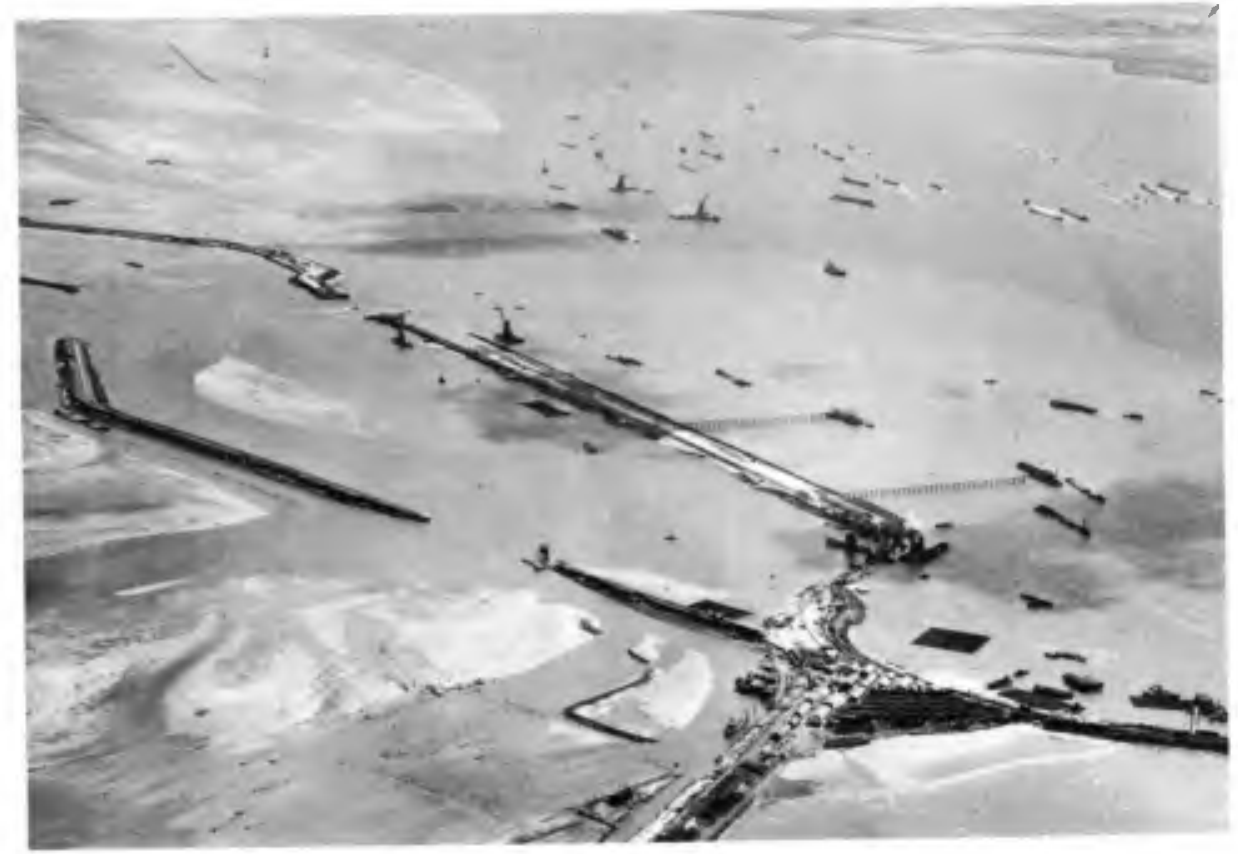

Fig. 16. General View.

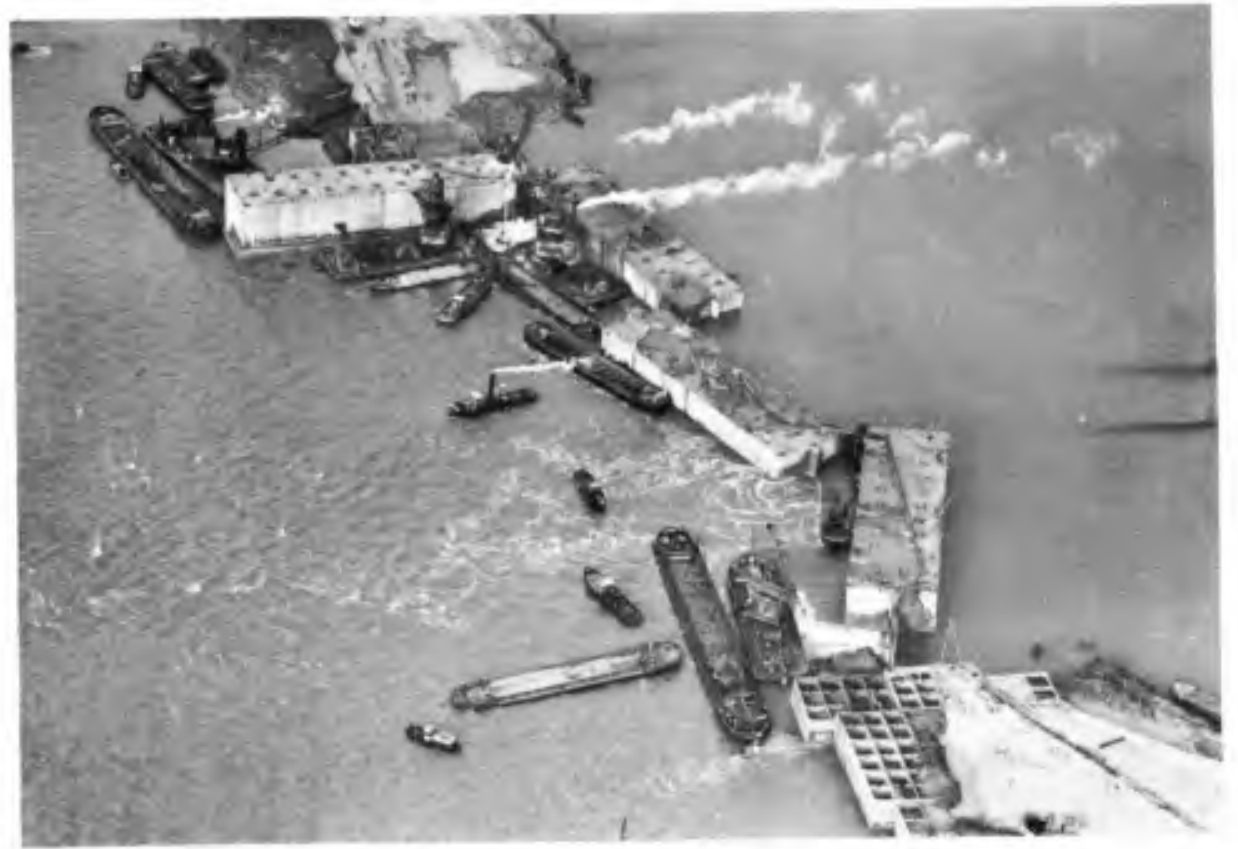

FIg. 17. East gap olosed with four Phoonix pontooss. 


\section{STROOMGATEM OUWERKERK}

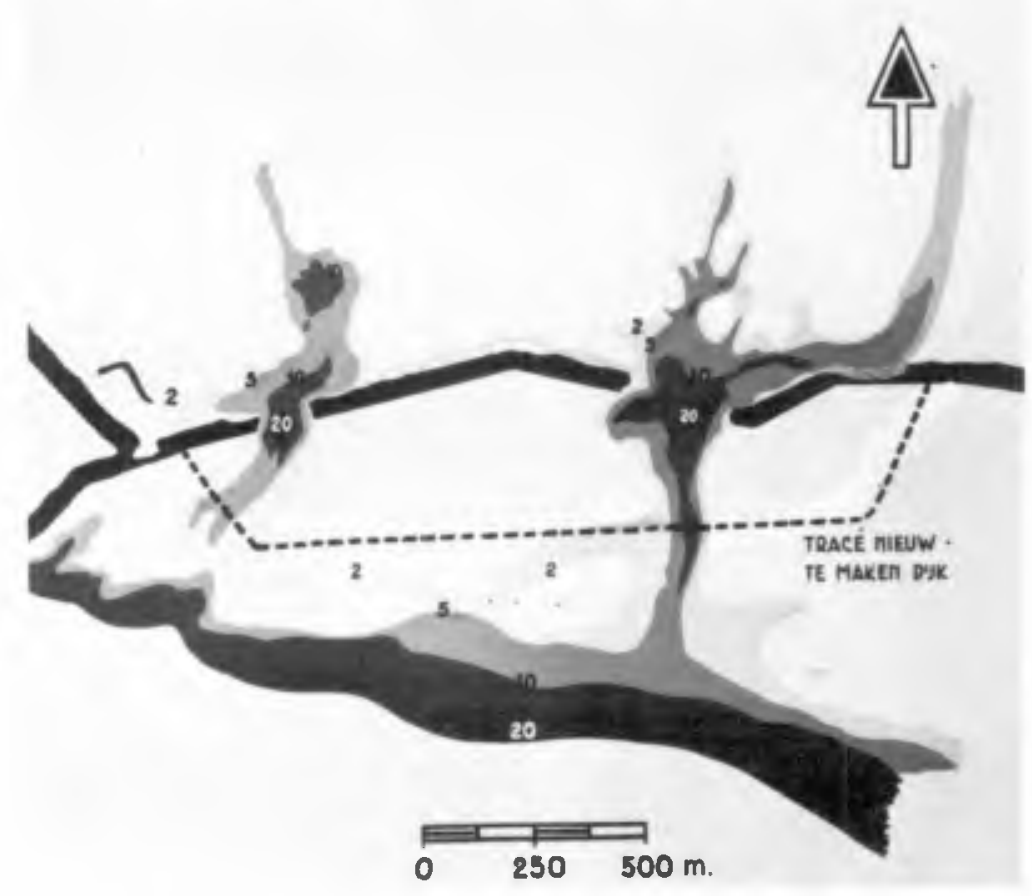

F1g. 15. Soheme for olosing breaches at Ouwerkerk.

Compared with Schelphoek it seemed to be a simple and straightforward affair, which proceeded exactly to schedule nearly to the very end. With the approach of the olosing operations which had been planned for the week of 20-25 August, diffioultios began to arise. Here again pontoons wore placed by way of abutments, in order to trim the gap down to the proper size for the closing pontoons. Almost imediately afterwards, the sill formed by dumping stone on mattresses in the west gap on which the pontoon was to rest began to sottle at the edgos. It bocame dangorously narrow and the dumping of additional stone did not yield material results. It seemed as if sand flowed from under the mattresses into the deep oxcavations at both sides of the sill. On the 22nd of August the abutment pontoons one after the other began to settlo and to tilt.

As at Sohelphoek, it was another case of now or much later, and as it was felt that with the available facilities for constructing mattresses and handling stone (it should be remembered that this coincided with the cruolal period at Scholphoek) did not insure gaining advantage over the erosion - espeoially with the spring tide approaching - it was again decided to venture on the bold course.

On Sunday 23 August 1953 two strings of five standard units each, 6 m high, were let down into the west gep at slack tide between flood and 


\section{COASTAL ENGINEERING}

ebb. It was a delicate operation because the time for maneluverinj was short and the narrow sill made it imperative to place both strings at a slight angle to each other with an accuracy of less than one meter. In the utmost tension the operation was carried out. After the fontoous had been sunk, it soon beceme evident that in the center throe units were slightly outward of their true position. They slid obliquely dovri, but then were held in a position with the top at about low water level.

In these circumstances it was not possible to close the east gap on the next day, as had been planned. This would have meant an important increase in the pressure on the pontoons in the west gap, because the level within the polder then would have remined practically constant somewhat above mean sea level, and it was practically a certainty that at low water outside the entire pontoon berrier would have keen swept away.

In that case there would have baen left a $400 \mathrm{~m}^{3}$ gap with maximum velocities of $5 \frac{1}{2}$ or $6 \mathrm{~m} / \mathrm{sec}$. There was no other possibility but to try to consolidate the barrier in the west gap first. This was eventually done by means of additional pontoons, stone, clay and finally sand. But meanwile the flow through the east gap increased to $5 \mathrm{~m} / \mathrm{sec}$ and in a few days the bed protection together with the abutment pontoons became a shambles. Every thought of using this gap as a site for a closing operation by pontoons had to be abandoned. Fig. 16 shows a general view of the situation at this stage.

After careful survey of the new state of affairs by sounding, gauge-reading and flow measuring, an entirely new scheme was eventually developed. This consisted in prepering a new site for placing a pontoon barrier fust outside the breach in the old dike. Four phoenix AX pontoons were to be sunk on a bed of brushwood mattresses and stone at 10 to $15 \mathrm{~m}$ depth. As the enclosure dam at Schelphook by this time was fairly well consolidated, it was possible to concentrate a larger portion of the equipment and manpower on ouwerkerk. Favored by the exceptionally fair autumn woather, the work proceeded practically without incident so that in the night of 6 to 7 November the last pontoon could be placed acoording to schedule (Pig. 17).

The old motto of the Province Zealand: "Luctor et Fengor", once more had been made good. 